\title{
Heterogeneous ice nucleation activity of bacteria: new laboratory experiments at simulated cloud conditions
}

\author{
O. Möhler ${ }^{1}$, D. G. Georgakopoulos ${ }^{2}$, C. E. Morris ${ }^{3}$, S. Benz ${ }^{1}$, V. Ebert $^{4}$, S. Hunsmann ${ }^{4}$, H. Saathoff ${ }^{1}$, M. Schnaiter ${ }^{1}$, \\ and R. Wagner ${ }^{1}$ \\ ${ }^{1}$ Institute for Meteorology and Climate Research (IMK-AAF), Forschungszentrum Karlsruhe, Germany \\ ${ }^{2}$ Department of Agricultural Biotechnology, Agricultural University of Athens, Greece \\ ${ }^{3}$ INRA, Unité de Pathologie Végétale UR407, Montfavet, France \\ ${ }^{4}$ Institute for Physical Chemistry, University of Heidelberg, Germany
}

Received: 11 February 2008 - Published in Biogeosciences Discuss.: 7 April 2008

Revised: 27 August 2008 - Accepted: 29 August 2008 - Published: 21 October 2008

\begin{abstract}
The ice nucleation activities of five different Pseudomonas syringae, Pseudomonas viridiflava and Erwinia herbicola bacterial species and of Snomax ${ }^{\mathrm{TM}}$ were investigated in the temperature range between -5 and $-15^{\circ} \mathrm{C}$. Water suspensions of these bacteria were directly sprayed into the cloud chamber of the AIDA facility of Forschungszentrum Karlsruhe at a temperature of $-5.7^{\circ} \mathrm{C}$. At this temperature, about $1 \%$ of the Snomax ${ }^{\mathrm{TM}}$ cells induced immersion freezing of the spray droplets before the droplets evaporated in the cloud chamber. The living cells didn't induce any detectable immersion freezing in the spray droplets at $-5.7^{\circ} \mathrm{C}$. After evaporation of the spray droplets the bacterial cells remained as aerosol particles in the cloud chamber and were exposed to typical cloud formation conditions in experiments with expansion cooling to about $-11^{\circ} \mathrm{C}$. During these experiments, the bacterial cells first acted as cloud condensation nuclei to form cloud droplets. Then, only a minor fraction of the cells acted as heterogeneous ice nuclei either in the condensation or the immersion mode. The results indicate that the bacteria investigated in the present study are mainly ice active in the temperature range between -7 and $-11^{\circ} \mathrm{C}$ with an ice nucleation (IN) active fraction of the order of $10^{-4}$. In agreement to previous literature results, the ice nucleation efficiency of Snomax ${ }^{\mathrm{TM}}$ cells was much larger with an IN active fraction of 0.2 at temperatures around $-8^{\circ} \mathrm{C}$.
\end{abstract}

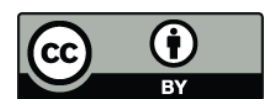

Correspondence to: O. Möhler

(Ottmar.Moehler@imk.fzk.de)

\section{Introduction}

Numerous organisms, including plants, invertebrates and microorganisms, can catalyze the freezing of supercooled water, i.e. they can act as heterogeneous ice nuclei. This property is generally due to the production of proteins or proteinaceous compounds (see Morris et al., 2004, for a review). Some of these proteins are particularly efficient ice nuclei, being able to induce freezing at temperatures just below $0^{\circ} \mathrm{C}$, and are among the most active of the naturally occurring heterogeneous ice nuclei (Lee et al., 1995). Strains of the bacterium Pseudomonas syringae, in particular, can express ice nucleation activity at -1 or $-2^{\circ} \mathrm{C}$.

The bacterium Pseudomonas syringae colonises plant surfaces from where it is emitted into the atmosphere. Net upward flux of $P$. syringae has been recorded at rates of about $30 \mathrm{~m}^{-2} \mathrm{~s}^{-1}$ above plant canopies (Lindemann et al., 1982). Such emission from plant canopies is apparently effective in transporting this bacterium up into clouds where it has been detected by a few research teams (Sands et al., 1982; Jayaweera and Flanagan, 1982; Amato et al., 2007). Ice nucleation (IN) active strains of $P$. syringae have also been detected in rain and snow (Constantinidou et al., 1990; Morris et al., 2008) and in diverse substrates outside of agricultural contexts suggesting that they are disseminated via the water cycle (Morris et al., 2008).

Because of the importance of the ice phase in clouds in the initiation of precipitation, a role for ice nucleation active bacteria in rain and snowfall has long been suspected (see Möhler et al., 2007, for a review). In fact it requires so-called ice nuclei, i.e. solid aerosol particles with specific surface properties, to freeze supercooled water droplets at temperatures above $-35^{\circ} \mathrm{C}$. Once formed, the ice phase in clouds

Published by Copernicus Publications on behalf of the European Geosciences Union. 
Table 1. Overview of samples prepared for the experiments. The cell number concentration was obtained from microscopic analysis for the Snomax ${ }^{\mathrm{TM}}$ suspensions and from optical density measurements for the living cell suspensions.

\begin{tabular}{lll}
\hline Sample & Type of bacteria & Cell concentration $\left(\mathrm{ml}^{-1}\right)$ \\
\hline SM1 & Snomax $^{\mathrm{TM}}$ & $7 \times 10^{8}$ \\
SM2 & Snomax $^{\mathrm{TM}}$ & $7 \times 10^{7}$ \\
PS1 & P. viridiflava FMu107 & $1 \times 10^{9}$ \\
& P. syringae IceHv & \\
PS2 & P. syringae 31R1 & $1 \times 10^{9}$ \\
PS3 & P. syringae Cit7 & $1 \times 10^{9}$ \\
EH1 & E. herbicola 268 Rb-2 & $9 \times 10^{8}$ \\
\hline
\end{tabular}

grows and multiplies by a sequence of processes eventually leading to precipitation. The warmer the freezing temperature the more time the ice particles have to take part in this sequence and the more likely they are to grow to precipitation size. It was shown in previous studies that bacteria are candidates for effective ice nuclei at such warm temperatures (Maki et al., 1974; Vali et al., 1976; Yankofsky et al., 1981; Levin and Yankofsky, 1983; Ward and DeMott, 1989).

Up to now it is however not clear which are the sources and number concentrations of the species of most importance in cloud evolution and how efficient those species are in acting as ice nuclei under the conditions of atmospheric clouds. To address the latter question, new series of ice nucleation experiments with bacteria have been started in the AIDA (Aerosol Interaction and Dynamics in the Atmosphere) facility of Forschungszentrum Karlsruhe. Under humidity and temperature conditions of expanding cloud parcels, the efficiency of some selected Pseudomonas syringae, Pseudomonas viridiflava and Erwinia herbicola species to induce ice nucleation in the immersion and condensation freezing mode were investigated at temperatures between -5 and $-15^{\circ} \mathrm{C}$. Experiments with Snomax ${ }^{\mathrm{TM}}$ have also been performed for comparison with previous studies (Ward and DeMott, 1989; Wood et al., 2002).

\section{Preparation of bacterial cells}

All samples were prepared as suspensions in nanopure water for later dispersion of the bacterial cells into the aerosol phase (see Sect. 4.2). Table 1 summarises some properties of the six different suspensions. Snomax ${ }^{\mathrm{TM}}$ pellets from York Snow Inc. were used to prepare samples SM1 and SM2. Snomax ${ }^{\mathrm{TM}}$ is an industrial product of strain $P$. syringae $31 \mathrm{R} 1$ grown under conditions (proprietary information) to maximize the ice nucleation activity. Snomax ${ }^{\mathrm{TM}}$ is used to initiate rapid freezing of droplets from spray guns that are used by ski areas for artificial snow making. The SM1 and SM2 samples were prepared with a Snomax ${ }^{\mathrm{TM}}$ mass concentration of 1.0 and $0.1 \mathrm{mg} \mathrm{ml}^{-1}$, respectively.

For ice nucleation experiments with living bacteria we selected strains that were known from previous studies to show high ice nucleation activity (INA) at temperatures between 0 and $-10^{\circ} \mathrm{C}$ when grown appropriately. Some samples were tested for their INA with the droplet freezing method as described in Sect. 3. The cells were grown on petri dishes containing King's B agar (King et al., 1954) for 3 days at $25^{\circ} \mathrm{C}$. Petri dishes were then transferred to $4^{\circ} \mathrm{C}$ and were stored for one week. Storage of the cells at this temperature for a few days enhances their ice nucleation activity. After this period of storage, they were washed off the plates with sterile distilled water, centrifuged to separate traces of the substrate and resuspended again in sterile distilled water. The suspension was adjusted to an optical density of 0.6 at a wavelength of $580 \mathrm{~nm}$ which corresponds to a cell number concentration of about $1 \times 10^{9} \mathrm{ml}^{-1}$.

Sample PS1 was prepared as a bacteria mixture of strain Pseudomonas viridiflava FMu 107 and Pseudomonas syringae IceHv. The first bacterium is a very close relative of $P$. syringae and is often difficult to distinguish from $P$. syringae. This strain was isolated from Chinese cabbage that suffered frost damage at the onset of the period for frost risk (in storage and in the field) in Beijing, People's Republic of China (Morris et al., 1992). The strain P. syringae IceHv was isolated from field-grown barley in Avignon, France in the fall of 2005. The two samples were combined in order to get enough volume for several experiments with the same sample at different temperatures in the cloud simulation chamber (see Sect. 4.1). The strain P. syringae Cit7 was isolated from an orange tree in 1985, and $P$. syringae 31R 1 from corn in 1976 by Lindow (1982). The latter is also used for the production of Snomax ${ }^{\mathrm{TM}}$.

Two series of ice nucleation experiments, Bio02 and Bio03, were conducted with Snomax ${ }^{\mathrm{TM}}$ and the 5 different strains of living bacteria (see Sect. 4, Table 2). From the amount of suspension sprayed into the $84 \mathrm{~m}^{3}$ large aerosol vessel and the resulting cell number concentration obtained from respective aerosol measurements (see Sect. 4.2) we estimated the cell concentration in the suspension and in the Snomax ${ }^{\mathrm{TM}}$ pellets. Dispersion of $20 \mathrm{ml}$ of SM1 resulted in an aerosol cell concentration of about $160 \mathrm{~cm}^{-3}$. From this we calculate a total number of $1.4 \times 10^{10}$ cells in the aerosol vessel, a cell concentration of $7 \times 10^{8} \mathrm{ml}^{-1}$ in the SM1 sample, and a cell concentration of $7 \times 10^{8} \mathrm{mg}^{-1}$ in the Sno$\max ^{\mathrm{TM}}$ pellets used to prepare SM1. The Snomax ${ }^{\mathrm{TM}}$ mass concentration of sample SM2 was 10 times lower than that of SM1. Dispersion of $50 \mathrm{ml}$ resulted in a cell concentration of $40 \mathrm{~cm}^{-3}$ in the aerosol phase, a total number of $3.4 \times 10^{9}$ cells in the aerosol vessel, a cell concentration of $7 \times 10^{7} \mathrm{ml}^{-1}$ in the SM1 sample, and a cell concentration of $7 \times 10^{8} \mathrm{mg}^{-1}$ in the Snomax ${ }^{\mathrm{TM}}$ pellets, which agrees with the cell concentration obtained from SM1. 
Table 2. Parameters of AIDA experiments and measured ice active fractions of bacterial cells. $V_{s}$ is the sample volume of the bacterial suspension directly sprayed into the AIDA cloud chamber (spray experiments with 0 pump speed). The resulting aerosol remained in the chamber for the following experiment with expansion cooling by pumping (expansion experiments with $60 \%$ pump speed). $p$ and $T_{g}$ are the initial pressure and temperature in the cloud chamber, and $n_{a e}, n_{\text {cells }}$, and $n_{i}$ the measured number concentrations of total aerosol, bacterial cell, and ice particles, respectively. The ice active cell fraction $f_{\mathrm{INA}}$ is the ratio of $n_{i}$ to $n_{\text {cells }}$, and $T_{i}$ the temperature at which the peak of ice formation was observed.

\begin{tabular}{lllllllllll}
\hline \multicolumn{2}{l}{ Type of experiment } & \multicolumn{4}{c}{ Initial parameters } & \multicolumn{5}{c}{ Ice nucleation results } \\
$\begin{array}{l}\text { Exp. } \\
\text { key }\end{array}$ & $\begin{array}{l}\text { Bacteria } \\
\text { sample }\end{array}$ & $\begin{array}{l}V_{S} \\
\mathrm{ml}\end{array}$ & $\begin{array}{l}\text { Pump } \\
\text { speed }(\%)\end{array}$ & $\begin{array}{l}p \\
\mathrm{hPa}\end{array}$ & $\begin{array}{l}{ }^{\circ} \mathrm{C} \\
\mathrm{C}\end{array}$ & $\begin{array}{l}n_{a e} \\
\mathrm{~cm}^{-3}\end{array}$ & $\begin{array}{l}n_{\text {cells }} \\
\mathrm{cm}^{-3}\end{array}$ & $\begin{array}{l}n_{i} \\
\mathrm{~cm}^{-3}\end{array}$ & $f_{\text {INA }}$ & $\begin{array}{l}T_{i} \\
{ }^{\circ} \mathrm{C}\end{array}$ \\
\hline Bio02_04 & SM1 & 20 & 0 & 1020.8 & -5.6 & 5500 & 160 & 2 & 0.01 & -5.6 \\
Bio02_05 & SM1 & 0 & 60 & 1020.0 & -5.7 & 4450 & 150 & 40 & 0.2 & $-8 \pm 1$ \\
Bio02_06 & PS1 & 20 & 0 & 1010.0 & -5.8 & 18000 & 290 & $<0.1$ & $<0.0003$ & -5.8 \\
Bio02_07 & PS1 & 0 & 60 & 1008.0 & -5.9 & 17000 & 275 & 1 & 0.004 & $-10 \pm 1$ \\
Bio02_09 & PS1 & 20 & 0 & 1002.1 & -9.7 & 12800 & 300 & 1 & 0.005 & -9.7 \\
Bio02_10 & PS1 & 0 & 60 & 1002.0 & -9.8 & 12250 & 280 & $<0.1$ & $<0.0004$ & $-13 \pm 3$ \\
\hline Bio03_06 & SM2 & 50 & 0 & 1005.0 & -5.7 & 13300 & 38 & $<0.1$ & $<0.003$ & -5.7 \\
Bio03_07 & SM2 & 0 & 60 & 1005.1 & -5.8 & 11700 & 43 & 10 & 0.23 & $-8 \pm 1$ \\
Bio03_08 & PS2 & 50 & 0 & 1006.0 & -5.6 & 4800 & 311 & $<0.1$ & $<0.0003$ & -5.6 \\
Bio03_09 & PS2 & 0 & 60 & 1005.9 & -5.7 & 4400 & 316 & 1 & 0.0032 & $-8 \pm 1$ \\
Bio03_11 & PS3 & 50 & 0 & 1005.0 & -5.7 & 6300 & 195 & $<0.1$ & $<0.0005$ & -5.7 \\
Bio03_12 & PS3 & 0 & 60 & 1005.1 & -5.8 & 4900 & 155 & 0.2 & 0.0013 & $-8 \pm 1$ \\
Bio03_19 & EH1 & 100 & 0 & 1008.0 & -5.7 & 2736 & 177 & $<0.1$ & $<0.0006$ & -5.7 \\
Bio03_20 & EH1 & 0 & 60 & 1008.0 & -5.8 & 2455 & 150 & 0.1 & 0.0007 & $-9 \pm 1$ \\
\hline
\end{tabular}

\section{Droplet freezing experiments}

The bacterial suspensions used for the Bio02 set of experiments were tested for their INA behaviour with the droplet freezing method as described by Lindow (1982). The results of these freezing tests were used to determine the optimum starting temperatures and cell concentrations for the AIDA ice nucleation experiments. Briefly, a set of $20 \mu \mathrm{l}$ droplets from tenfold dilutions of a bacterial suspension is placed on a paraffin-coated aluminium foil, placed on a cooling bath. The temperature of the bath is then lowered and the number of frozen drops at each temperature (at 1 degree intervals after a $30 \mathrm{~s}$ delay) is recorded. By taking into account the concentration of bacteria, it is possible to estimate the concentration of ice nuclei for each temperature and, therefore, the ice nucleation-active proportion of the bacterial population. In this way we obtained for sample PS1 an IN active cell number concentration of about $7 \times 10^{3} \mathrm{ml}^{-1}$ at a temperature of $-9^{\circ} \mathrm{C}$. By dividing through the total cell concentration of $1 \times 10^{9} \mathrm{ml}^{-1}$ we obtain an IN active cell fraction of $7 \times 10^{-6}$ at the same temperature.

\section{Cloud chamber experiments}

The immersion and condensation freezing efficiencies of bacterial cells suspended in the aerosol phase were investigated at temperatures between -5 and $-20^{\circ} \mathrm{C}$. The experiments were performed in the AIDA (Aerosol Interaction and
Dynamics in the Atmosphere) facility of Forschungszentrum Karlsruhe. Experimental parameters and results are summarised in Table 2. The aerosol of single bacterial cells was generated by spraying the bacterial suspensions prepared as described in Sect. 2 through a nozzle directly into the AIDA chamber. The spray process was used to estimate the INA of the bacterial cells. Such experiments, hereafter termed spray experiments, will be described in Sect. 4.3. ADIA was then operated as a pumped expansion chamber (Möhler et al., 2005, 2006) to investigate the IN activity of the bacterial cells at simulated temperature and humidity conditions in updraughting air parcels of atmospheric clouds. Such experiments, hereafter termed expansion experiments, will be described in Sect. 4.4.

\subsection{The AIDA cloud chamber facility}

Briefly, the AIDA facility consists of a cylindrical aluminium vessel with a volume of $84 \mathrm{~m}^{3}$. This vessel was used as a cloud simulation chamber for the spray and cloud expansion experiments. The vessel is located in a thermally insulating box. An air ventilation, heating, and cooling system controls the temperature inside this box in the range from 60 to $-90^{\circ} \mathrm{C}$. In preparation of the experiments, temperature changes are normally actuated during the night hours in order to approach the desired starting temperature at a rate of about $4 \mathrm{~K} / \mathrm{h}$. During the experiments, the cooling system is operated at constant temperature control with temporal and spatial variability below $\pm 0.3 \mathrm{~K}$ throughout the cold box and 


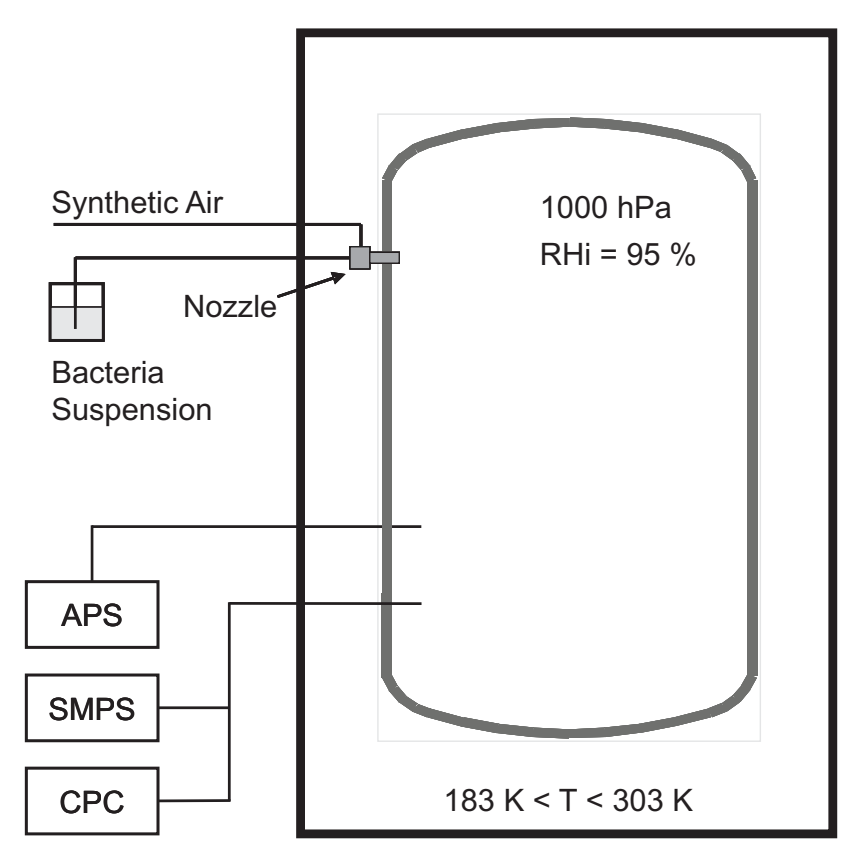

Fig. 1. Schematic of experimental setup for aerosol generation and characterisation.

the cloud chamber. Also during the evening and night hours, the cloud chamber is cleaned by pumping to a pressure below $1 \mathrm{hPa}$, flushing with dry synthetic air, and filling with particle free humid air. The particle background after filling to atmospheric pressure is normally below $0.1 \mathrm{~cm}^{-3}$. Experiments were started at a pressure between 1002 and $1021 \mathrm{hPa}$ (see Table 2). At constant temperature and pressure conditions, a high relative humidity between 90 and $95 \%$ is maintained inside the cloud simulation chamber by a partial dew or, at lower wall temperatures, ice coverage of the inner chamber walls.

The AIDA facility is equipped with a comprehensive set of water, aerosol, and cloud instruments (Möhler et al., 2005, 2006). For the present study we used the chilled mirror frost point hygrometer LX-373 from MBW Calibration Ltd. in Switzerland for total water concentration measurements. The in situ high-resolution diode laser absorption spectrometer APicT-DLAS (Ebert et al., 2005) is used for fast and sampling-free open-path water vapour measurements inside the AIDA vessel. The water vapour concentration was measured directly within the cloud by using a fibre-coupled, open-path, White-type absorption cell with an absoption path length of $23.6 \mathrm{~m}$ inside the cloud chamber (see Mangold et al., 2005, for more details). During the Bio02 and Bio03 experiments the APicT-DLAS measured with a $1.5 \mathrm{~s}$ temporal resolution and concentration resolution of about $20 \mathrm{ppb}$.

Aspherical aerosol particles as well as growing water droplets and ice particles were sensitively detected with the in situ light scattering and depolarisation setup SIMONE. This instrument measures the depolarisation of polarised laser light of $488 \mathrm{~nm}$ wave lenght scattered from particles in the center of the cloud chamber to a scattering angle of $176^{\circ}$. Any scattering depolarisation ratio (SDR) signal larger than the background level of about 0.04 clearly indicates the presence of aspherical particles in the cloud chamber. These can be either bacterial cells, which are known to be aspherical, or ice particles growing to larger sizes after their nucleation by IN active bacteria immersed in droplets.

The number concentration of droplets and ice particles was measured with two optical particle counters Welas and Welas2 from Palas GmbH Karlsruhe, Germany (Benz et al., 2005). Both instruments are located below the cloud chamber and measure the concentration of particles larger than about $0.5 \mu \mathrm{m}$ (Welas) and $6 \mu \mathrm{m}$ (Welas2) in a sample flow taken from the chamber volume through a vertical stainless steel sampling tube. Because ice particles quickly grow to larger sizes under the conditions of the AIDA experiments, they can clearly be distinguished and separated from the smaller droplets and aerosol particles (see Figs. 4 to 7). The detection limit of the Welas instruments is about $0.1 \mathrm{~cm}^{-3}$, the uncertainty of ice concentration measurements is about $\pm 30 \%$. An infrared extinction spectrometer (FTIR) was used to characterise droplet and ice clouds (Wagner et al., 2006). The number concentrations and size distribution of aerosols were measured with two condensation particle counters (CPC3010, CPC3025), the scanning mobility particle sizer (SMPS) and the aerodymamic particle spectrometer (APS), all from TSI.

\subsection{Aerosol formation and characterisation}

Figure 1 schematically shows the experimental setup for aerosol formation and characterisation. Bacterial suspensions were prepared as described in Sect. 2 and directly sprayed into the cloud chamber. The spray cloud was generated with a two-component jet device (model 970 from Düsen-Schlick GmbH, Germany) which uses a particle free synthetic air flow of about $11 \mathrm{~min}^{-1}$ at an absolute pressure of 2 bar to disperse a liquid flow of about 5 to $10 \mathrm{ml} \mathrm{min}^{-1}$. It took about $5 \mathrm{~min}$ to disperse the sample volumes of 20 to $100 \mathrm{ml}$ (see Table 2). The dispersion nozzle was heated to about $20^{\circ} \mathrm{C}$. Thus, when entering the cloud chamber, the bacterial cells were immersed in warm water droplets, but the droplets quickly cooled to the temperature of the cloud chamber volume and, at the same time, started to evaporate. Further details of the spray process and measurements of ice nucleation during spray experiments will be discussed in Sect. 4.3.

After all the droplets evaporated within about 5 to $10 \mathrm{~min}$, the resulting aerosol size distributions were measured with the SMPS and APS aerosol instruments. The two instruments were operated outside the cold box (Fig. 1) and connected to the cloud chamber with stainless steel sampling tubes. Particle losses in the sampling tubes can be neglected for all aerosols used in this study. It should be noted here 


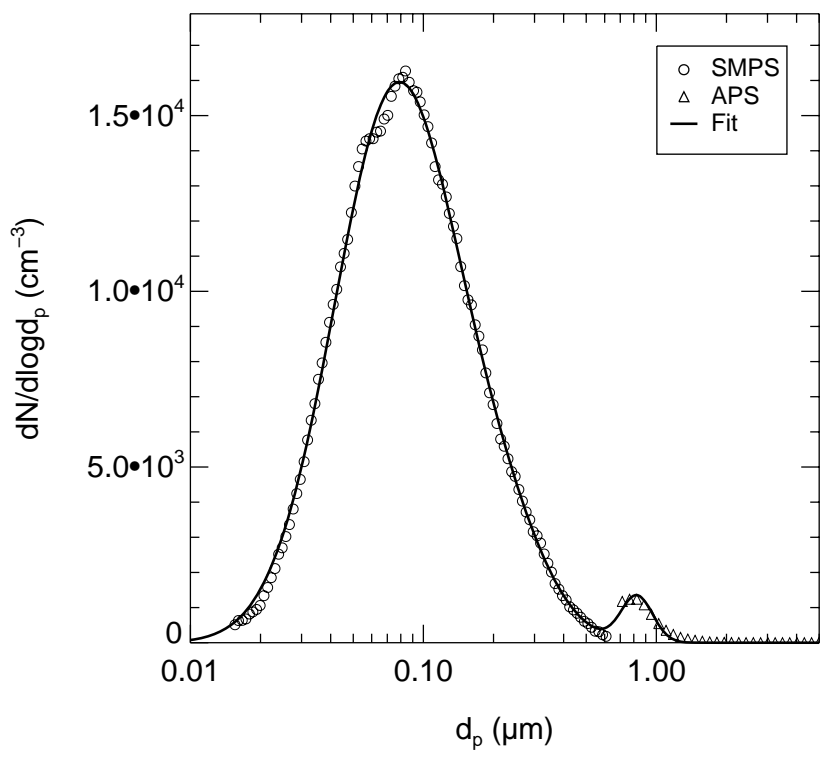

Fig. 2. Size distribution of Snomax ${ }^{\mathrm{TM}}$ aerosol measured before expansion experiment Bio03_07 with the scanning mobility particle spectrometer SMPS (circles) and the aerodynamic particle spectrometer APS (tiangles). The size distribution clearly reveals the bi-modal nature of the aerosol with smaller residual particles from evaporated droplets which didn't contain intact bacterial cells and the larger, but less abundant, bacterial cell particles with diameters around $0.8 \mu \mathrm{m}$. The sum of two lognormal size distribution (solid line) was fitted to the data.

that the SMPS system measures the electrical mobility size and the APS the aerodynamic size of aerosol particles. These diameters are different for particles which are aspherical, and therefore have a dynamic shape factor larger than one, or which have a density different from $1 \mathrm{~g} \mathrm{~cm}^{-3}$. Because bacterial cells are known to be aspherical, the SMPS and APS diameters were converted into the so-called volume-equivalent sphere diameter, i.e. the diameter of a spherical particle having the same terminal settling velocity as the particles measured with the SMPS and APS. Best match of the transferred SMPS and APS size distributions was achieved with a density of $1 \mathrm{~g} \mathrm{~cm}^{-3}$ and a dynamic shape factor of about 1.1 to 1.3. The aspherical nature of the bacterial cells in the aerosol phase was also reflected by an enhanced depolarisation ratio of scattered light measured with SIMONE during and after adding the bacterial cells to the cloud chamber (see Sect. 5 .

Figures 2 and 3 show two examples of size distributions measured before the start of experiments Bio03_07 and Bio03_09. Both examples reveal the clear bimodal structure of the aerosol which was observed in all experiments. The reason for that is that only a minor fraction of the droplets generated by the spray nozzle contained a bacterial cell. The mode of smaller particles can therefore be explained as residual particles of evaporating droplets without a bacterial cell. The smaller but more narrow mode of larger particles shows

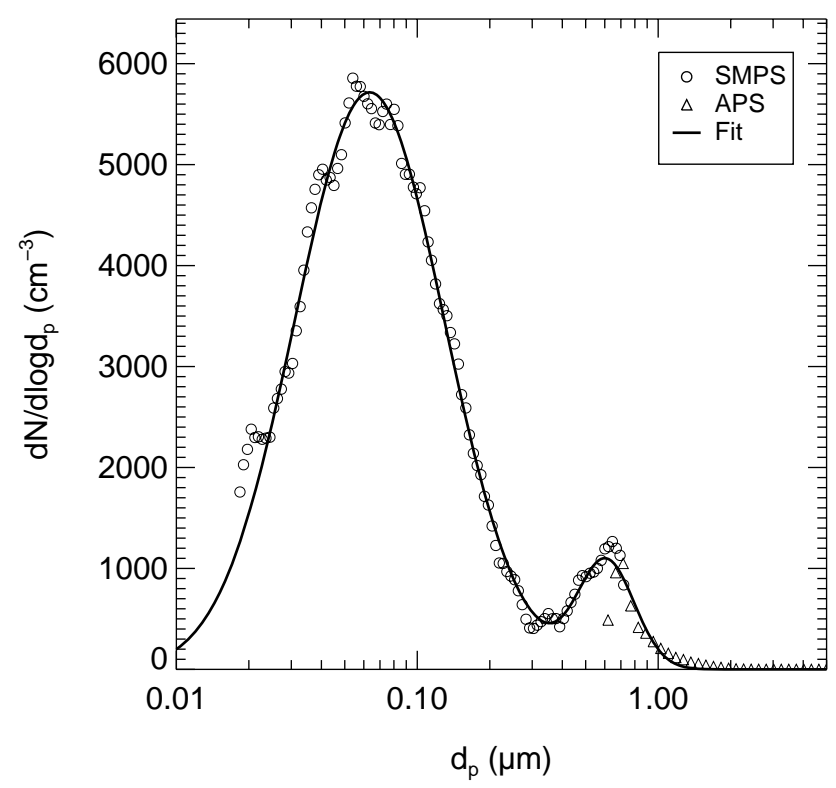

Fig. 3. Same as Fig. 2 for $P$. syringae $31 \mathrm{R} 1$ of experiment Bio03_09. In this example the mode of bacterial cell particles has a median diameter of $0.6 \mu \mathrm{m}$.

the size distribution of the bacterial cells in the aerosol phase. The larger mode size of about $0.8 \mu \mathrm{m}$ for Snomax ${ }^{\mathrm{TM}}$ (Fig. 2) and $0.6 \mu \mathrm{m}$ for P. syringae 31R1 (Fig. 3) is in good agreement with the expected size of single bacterial cells.

In some cases the larger mode of cell particles showed a tail towards larger particle diameters. This can be explained by a minor fraction of agglomerate particles of 2 or more bacterial cells originating from larger droplets which contained the respective number of cells after dispersion. Because of the low number concentrations of cell particles (see below), the formation of larger cell agglomerates by coagulation can be neglected on the time scales of the experiments.

The sum of two lognormal size distribution was fitted to the measured data, shown as solid lines in Figs. 2 and 3. The number concentration $n_{a e}$ of the total aerosol, i.e. the sum of both modes, and the number concentration $n_{\text {cells }}$ of the bacterial cells in the larger mode were obtained from the lognormal fits. The results are listed in Table 2. The size distribution fit result for $n_{a e}$ was in good agreement with the aerosol number concentrations directly measured with the condensation particle counter CPC 3025 and, for number concentrations below about $10000 \mathrm{~cm}^{-3}$ also with the CPC3010 instrument. With number concentration between about 30 and $300 \mathrm{~cm}^{-3}$ the bacterial cells in the cloud chamber were about a factor 6 to 60 less abundant than the residual particles.

\subsection{Spray experiments}

During the formation of the spray cloud in the cold aerosol chamber we also looked for the formation of ice crystals by 


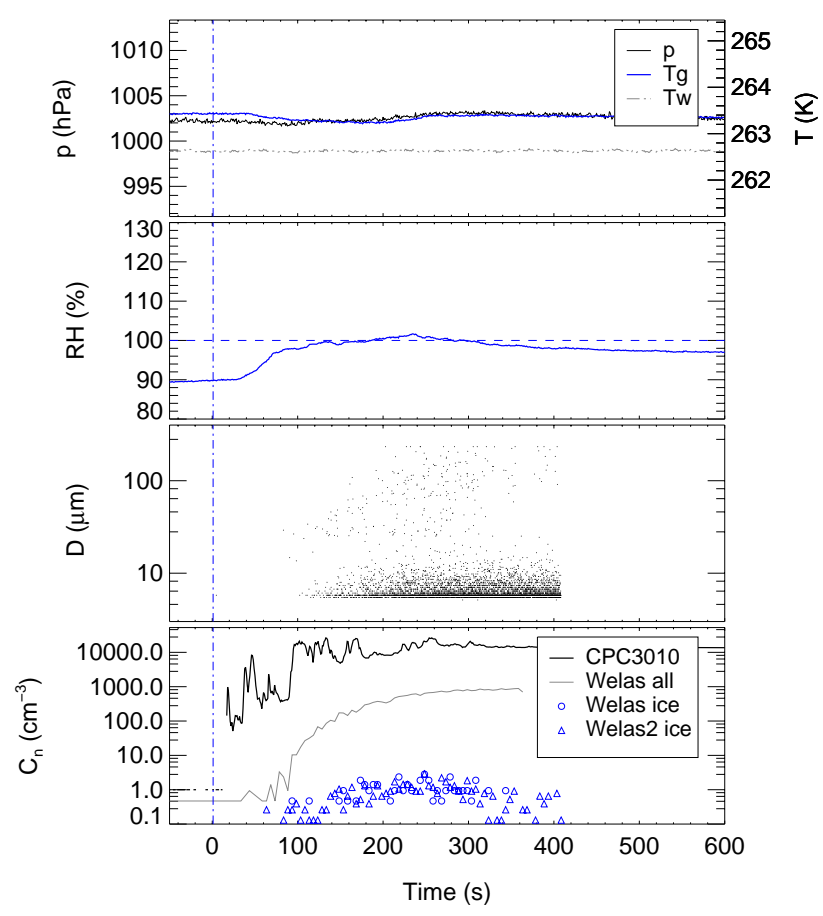

Fig. 4. Data time series from spray experiment Bio02_09 with PS1 aerosol with time in seconds relative to the start of the spray formation. The spray formation lasted from 0 to about $300 \mathrm{~s}$. Plotted are the aerosol vessel pressure $p$ (black line, panel 1), mean gas temperature $T_{g}$ (blue line, panel 1), and mean wall temperature $T_{w}$ (dash-dotted grey line, panel 1), the relative humidity with respect to liquid water, RH (blue line, panel 2), optical diameters $D$ of single particles (aerosol, droplet, or ice) from the Welas2 instrument (black dots, panel 3), as well as, in panel 4, the aerosol number concentrations measured with the CPC 3010 (black line), the number concentration of all particles in the detection range of the Welas instrument (Welas all, grey line), and the ice particle number concentrations measured with the two optical particle counters (Welas ice, blue circles and Welas2 ice, blue triangles).

heterogeneous ice nucleation of bacterial cells immersed in the cloud droplets. These so-called spray experiments were only sensitive to immersion freezing of the cells. Examples are shown in Figs. 4 and 5 for the spray experiments Bio02_09 and Bio03_08, respectively. The different panels show data time series of the aerosol vessel pressure $p$, mean gas temperature $T_{g}$ and mean wall temperature $T_{w}$, the relative humidity with respect to liquid water, $\mathrm{RH}$, the scattering depolarisation signal SDR from the SIMONE instrument (only in Fig. 5), the optical diameters $D$ of single particles (aerosol, droplet, or ice) from the Welas2 instrument, as well as particle number concentrations measured with the CPC3010, Welas, and Welas2 instruments.

The pressure and gas temperature are almost constant during the spray experiments. The time axis of Figs. 4 and 5 is plotted in seconds relative to the start of spray formation. The duration of spray formation was about $300 \mathrm{~s}$ in

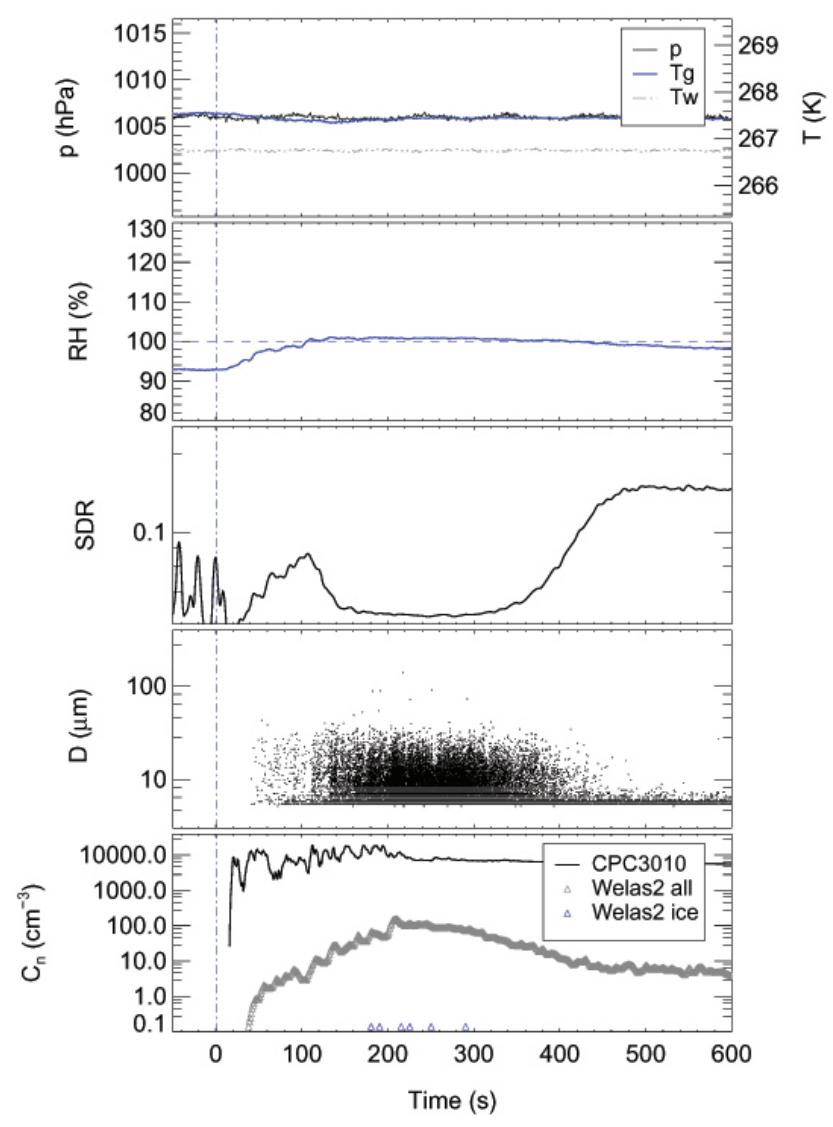

Fig. 5. Data time series from spray experiment Bio03_08 with strain $31 \mathrm{R} 1$ aerosol with time in seconds relative to the start of the spray formation. The spray formation lasted from 0 to about $200 \mathrm{~s}$. Panels 1 and 2 show the same type of data as in Fig. 4. Panel 3 depicts the scattering depolarisation signal SDR from the SIMONE instrument, panel 4 the optical diameters $D$ of single particles (aerosol, droplet, or ice) from the Welas2 instrument (black dots), and panel 5 the aerosol number concentrations measured with the CPC3010 (black line), the number concentration of all particles in the detection range of the Welas 2 instrument (Welas2 all, grey line), and the ice particle number concentrations measured with the Welas 2 instrument (Welas2 ice, blue triangles).

experiment Bio02_09 and $200 \mathrm{~s}$ in experiment Bio03_08. It can be seen in both examples that the relative humidity starts to rise with the spray formation due to the evaporation of the liquid water droplets in the cloud chamber. The humidity approaches water saturation, marked by the horizontal dashed blue line in panel 2, after about $1 \mathrm{~min}$. The aerosol number concentration also steeply rises with the spray formation. The CPC3010 measures both aerosol particles and residual particles from the water droplet and ice particles evaporating in the warm sampling tube of the instrument. The fluctuation of the aerosol concentration during the spray formation process reflects the inhomogeneous distribution of the spray cloud inside the aerosol chamber. The internal mixing time scale of the cloud chamber is of the order of $1 \mathrm{~min}$. 


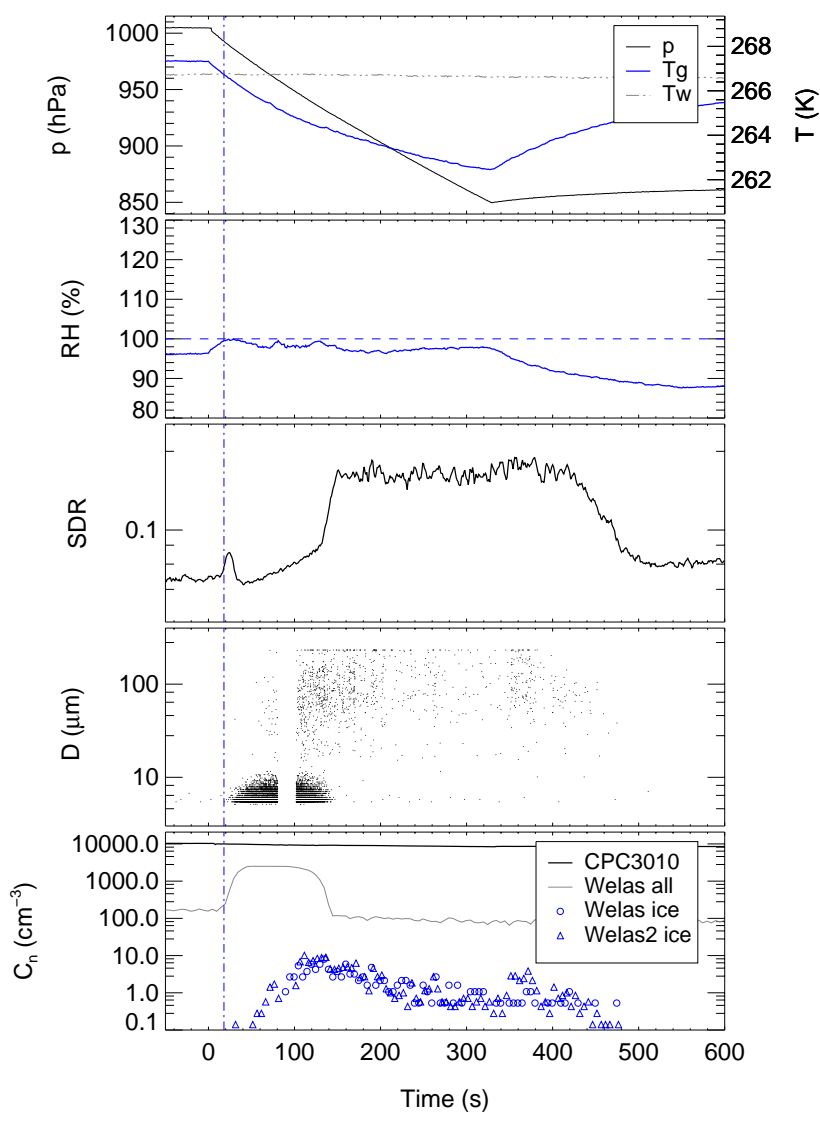

Fig. 6. Data time series from expansion experiment Bio03_07 with Snomax ${ }^{\mathrm{TM}}$ aerosol with time in seconds relative to the start of pumping. The expansion cooling by pumping lasted from 0 to about 330 s. Panels 1 to 4 depict the same type of data as in Fig. 5. Panel 5 shows the aerosol number concentrations measured with the CPC3010 (black line), the number concentration of all particles in the detection range of the Welas instrument (Welas all, grey line), and the ice particle number concentrations measured with the Welas instrument (Welas ice, blue circles) and with the Welas2 instrument (Welas2 ice, blue triangles).

A homogeneous aerosol distribution is quickly reached after spray formation is stopped.

As long as the humidity is still below water saturation at the beginning of the spray formation, the droplets quickly evaporate and are not detected with the optical particle counters. As soon as water saturation is reached, the droplet concentration in the cloud chamber increases as shown in panel 3 of Fig. 4 and panel 4 of Fig. 5. The droplets can clearly be identified as a dense area of black dots in the lower part of these panels with droplet diameters up to about $20 \mu \mathrm{m}$. A second group of larger ice particles with optical diameters up to about $200 \mu \mathrm{m}$ is only detected in experiment Bio02_09 (Fig. 4). During this experiment Welas2 data was only recorded for $400 \mathrm{~s}$ after experiment start. Therefore, the evaporation of the droplet and ice cloud is not detected.

No significant ice formation was observed during the spray

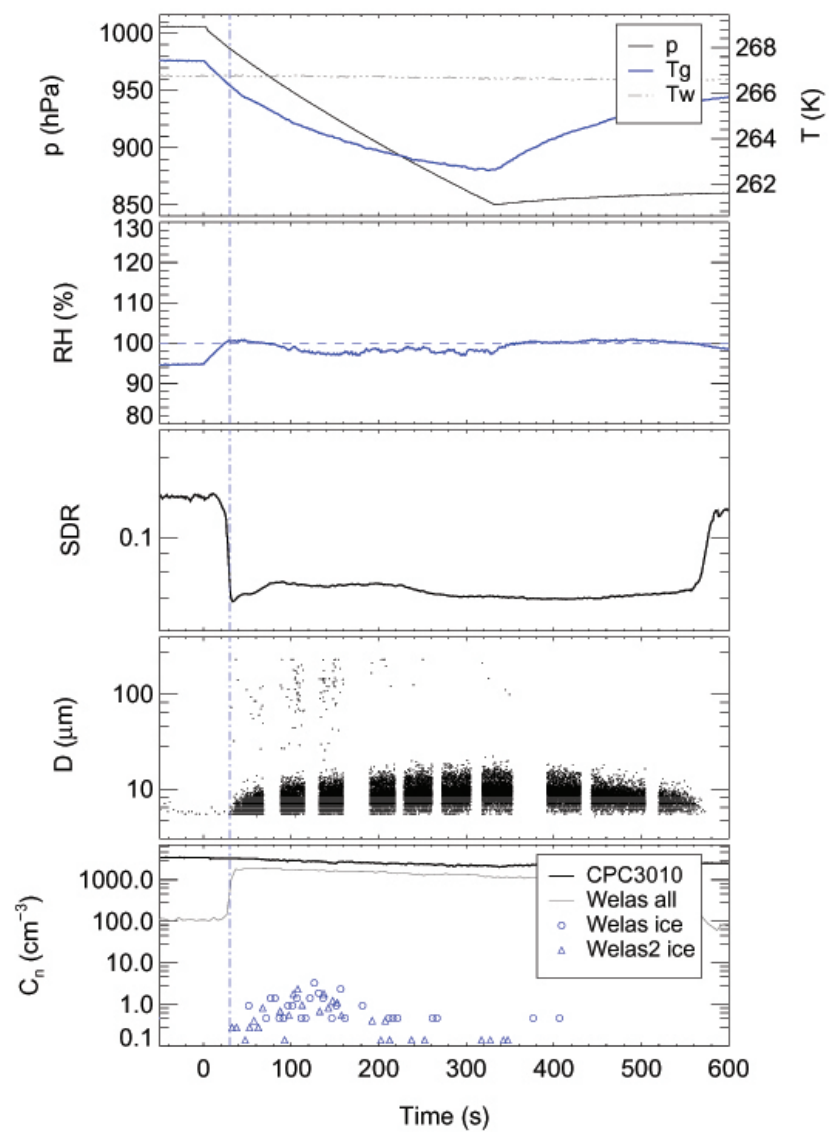

Fig. 7. Data time series from expansion experiment Bio03_07 with strain 31R1 aerosol with time in seconds relative to the start of pumping. The expansion cooling by pumping lasted from 0 to about 330 s. Plotted is the same type of data as in Fig. 6.

experiment Bio03_08 (Fig. 5). During this experiment, the spray droplets were completely evaporated after $450 \mathrm{~s}$. The scattering depolarisation ratio measured during this experiment (SDR, panel 3) starts to rise with the spray formation due to the aspherical bacterial cells added to the aerosol chamber. With an increasing abundance of liquid droplets in the chamber, indicated by the Welas 2 data in panel 4, the scattering signal is dominated by spherical droplets with almost no depolarisation. The SDR signal starts to rise again with the evaporation of the droplets and the release of the bacterial cells immersed in the droplets into the aerosol phase.

\subsection{Cloud expansion experiments}

After the bacterial suspensions were sprayed into the cloud chamber as described in Sects. 4.2 and 4.3, the efficiency of the bacterial cells in the condensation and immersion modes of freezing was investigated in dynamic expansion experiments. Examples of such expansion experiments are shown in Figs. 6 and 7 for Bio03_07 and Bio03_09, respectively. 
As in Fig. 5, the different panels show time series of pressure, gas and wall temperature, relative humidity with respect of water, backscattering depolarisation, optical diameter of individual aerosol and cloud particles, as well as aerosol, droplet, and ice particle number concentrations. The time axis of Figs. 6 and 7 is plotted in seconds relative to the start of pumping.

The expansion experiments were started at constant pressure and temperature conditions as given in Table 2. The pressure in the cloud chamber was then lowered by pumping to about $850 \mathrm{hPa}$ within a time period of about $5 \mathrm{~min}$ (solid black line in top panel). In all expansion experiments the same expansion rate was used by setting the pump speed to $60 \%$ of its maximum value. The pump speed is also listed in column 4 of Table 2 . A value of 0 indicates the spray experiments at constant pressure and temperature and a value of 60 the expansion experiments with dynamic changes of pressure, temperature, and humidity.

The expansion causes quasi-adiabatic cooling of the cloud chamber volume shown by the measured gas temperature $T_{g}$ in Figs. 6 and 7 (solid blue line in top panel). A mixing fan in the bottom part of the chamber forces homogeneous temperature and humidity conditions during the expansion. The wall temperature $T_{w}$ (dash-dotted line in top panel) stays almost constant all the time. The increasing difference between $T_{w}$ and $T_{g}$ causes an increasing heat flux from the chamber walls and thereby an increasing deviation of the temperature change from the adiabatic case.

The relative humidity $R H$ with respect to water, calculated from the measured water vapour partial pressure (see Sect. 4.1) and the water saturation pressure with respect to $T_{g}$ is shown in the second panel of Figs. 6 and 7 (solid blue line). Starting from about $95 \%$, the relative humidity increases due to the expansion cooling and approaches water saturation after about $40 \mathrm{~s}$ of pumping. At about the same time, the total number of particles measured with the optical particle counter Welas (grey line in the lower panel) steeply raises due to the activation and growth of water droplets. Panels 4 also clearly shows the formation of the droplet cloud with diameters up to about $10 \mu \mathrm{m}$ during Bio03_07 and about $15 \mu \mathrm{m}$ during Bio03_09. The same data sets clearly show the formation of larger ice particles with diameters up to about $200 \mu \mathrm{m}$. In both expamples no ice crystals are detected before the formation of the droplets was observed. The number of ice particles measured with two optical particle counters Welas and Welas 2 are shown in the lower panel of Figs. 6 and 7 (blue circles and triangles, respectively).

The FTIR extinction spectra measured at the same time (not shown in the figure) reveal that initially mainly water droplets are formed and that the number of droplets is close to the number of aerosol particles before droplet formation (black line in the lower panel). It should be noted that the CPC3010 measures the total particle concentration and does not distinguish between aerosol particles and droplets. The Welas instrument underestimates the total droplet concentration because some droplets are too small for optical detection. The third panels of Figs. 6 and 7 show the scattering depolarisation ratio (SDR). The SDR signals before start pumping, i.e. before cloud droplet and ice activation, are due to the bacterial cells alone. It can be seen that the P. Syringae bacteria of strain 31R1 gives a larger SDR than the Snomax ${ }^{\mathrm{TM}}$ cells, which means that the living cells are more aspherical.

\section{Results and discussion}

Two series of experiments were performed during the AIDA campaigns Bio02 in January 2006 and Bio03 in May 2006 (see Table 2). Experimental parameters and results are summarised in Table 2. Most of the experiments were started at an initial temperature $T_{g}$ of about $-5.7^{\circ} \mathrm{C}$. Only experiments Bio02_09 and Bio02_10 were started at a colder temperature of about $-9.7{ }^{\circ} \mathrm{C}$. The amount of sample volume $V_{s}$ sprayed into the cloud chamber is also given in Table 2 for the static experiments without pumping (zero pump speed). A value of zero in this column of the table indicates that the aerosol generated during the spray experiment before remained in the chamber for the subsequent expansion experiment.

As a main result from this work, the IN active cell fraction $f_{\text {INA }}$ was calculated from the ratio of the ice particle number concentration $n_{i}$ to the cell number concentration $n_{\text {cells. The }}$ estimated uncertainty for $f_{\text {INA }}$ is about $\pm 60 \%$. In case of the spray experiments with $\mathrm{Snomax}^{\mathrm{TM}}$ at $-5.7^{\circ} \mathrm{C}$, significant ice formation was only measured during Bio02_04 with an IN active fraction of about $1 \%$. For Bio03_06 only an upper limit of 0.003 could be given, which is in agreement to the Bio02_04 result within experimental uncertainty. This means that only $1 \%$ or less of the Snomax ${ }^{\mathrm{TM}}$ cells is ice-active at $-5.7^{\circ} \mathrm{C}$ in the immersion mode of freezing, at least within the evaporation timescale of the spray droplets which is of the order of a few seconds to a few minutes. In similar cloud expansion studies with Snomax ${ }^{\mathrm{TM}}$ Ward and DeMott (1989) found some IN active cells at a temperature around $-5^{\circ} \mathrm{C}$.

Figure 6 shows, as an illustrative example, how the number of ice particles increased during the expansion experiment Bio03_07 after droplets had formed. The formation of some ice crystals immediately after the activation of the first droplets is indicated in a small SDR peak next to the vertical blue line. The number of ice crystals was below the detection limit of the Welas instruments. The SDR then drops and approaches the background value because the few ice crystals rapidly grew to large sizes and settled to the floor of the cloud chamber. The major peak of ice formation occurred between 50 and $110 \mathrm{~s}$ of pumping time with the Welas ice number concentration increasing to a maximum value of $10 \mathrm{~cm}^{-3}$. This corresponds to an increase of the fraction of IN active cells from almost 0 to a maximum value of 0.23 within a narrow temperature range from about -7 to $-9^{\circ} \mathrm{C}$. At the same 
time, the depolarisation ratio starts to rise again, which also indicates the formation and growth of further ice crystals.

About $20 \mathrm{~s}$ after the ice particle concentration reached its maximum value, the droplets evaporated due to the so-called Bergeron-Findeisen mechanism. In other words, the lower saturation pressure of water above the ice particles compared to the supercooled water droplets lowers the relative humidity, as also indicated in the TDL measurements, and therefore induces growth of the ice volume in expense of the liquid droplet. The evaporation of the droplets is also indicated in the steep SDR increase. After all water droplets evaporated, which was confirmed by the FTIR measurements, the expansion still continued to a minimum temperature of about $-11^{\circ} \mathrm{C}$, but no further increase of $n_{i}$ was observed. This indicates that the remaining $77 \%$ of the not yet IN active cells didn't show detectable INA in the deposition mode of ice nucleation at temperatures as low as $-11^{\circ} \mathrm{C}$. The ice number concentration decreased with time due to settling losses of the larger ice crystals in the chamber, and about $150 \mathrm{~s}$ after pumping stopped the remaining ice crystals completely evaporated in the warming cloud chamber. Experiment Bio03_04 also revealed that about $20 \%$ of the Snomax ${ }^{\mathrm{TM}}$ cells are ice active between -7 and $-9^{\circ} \mathrm{C}$. This is in agreement to studies by Ward and DeMott (1989) and Wood et al. (2002) who also found strong ice nucleation efficiency of Snomax ${ }^{\mathrm{TM}}$ at these temperatures.

During experiment Bio03_09, ice particles also formed between about 50 and $110 \mathrm{~s}$ of pumping time (lowest panel in Fig 7), but with a tenfold lower number concentration. In this experiment, the initially higher SDR of the more aspherical bacteria (see above) dropped to almost the background value during the formation of the liquid cloud. This indicates that most of the bacterial cells are $\mathrm{CCN}$ active and transform from aspherical particles to spherical droplets without scattering depolarisation. The SDR rises again along with the formation of ice particles and decreases with the settling loss of the ice particles between 150 and $400 \mathrm{~s}$.

It should be noted that for the analysis of $f_{\mathrm{INA}}$ in the present study we assumed that only the cell particles but not the residual particles are ice-active and, in case of the expansion experiments, that most of the cell particles were activated to form cloud droplets. The first assumption was supported by the fact that no significant ice formation was observed at a temperature between -5.7 and $-11^{\circ} \mathrm{C}$ in an expansion experiment with a filtered Snomax ${ }^{\mathrm{TM}}$ suspension which resulted in a spray aerosol of only residual particles, but no larger bacterial cells. The second assumption also seems to be reasonable because bacterial cells have been found to be active cloud condensation nuclei at relatively low supersaturation with respect to water (Franc and DeMott, 1998; Bauer et al., 2003). So, at least if the cells are wettable, they are in favour for CCN activation due to their larger size compared to the residual particles. As discussed above also the SDR data indicates the CCN activation of bacterial cells.

In all spray experiments with living cells at $-5.7^{\circ} \mathrm{C}$ no sig- nificant ice formation was observed. During the expansion experiments the same strains were only slightly active at temperatures between -7 and $-11^{\circ} \mathrm{C}$ with IN active fractions of the order of $10^{-4}$. The lower ice-active fraction is also illustrated for experiment Bio03_09 in Fig. 7 which shows the same type of data as already discussed above for experiment Bio03_07. For the PS1 sample, a second spray experiment was performed at a temperature of $-9.7^{\circ} \mathrm{C}$ (Bio02_08, see also Fig. 4). At this temperature the observed IN active fraction was about 0.005 which is in good agreement to the value of 0.004 measured during the preceding experiment Bio02_07 at a similar temperature. This example demonstrates that IN active fractions measured in spray and expansion experiments at the same temperature agree to each other. Surprisingly, no significant ice formation was observed in the expansion experiment Bio02_10 with cooling to a minimum temperature of $-15.2^{\circ} \mathrm{C}$. This indicates that almost all IN active cells have been activated during the experiment Bio02_09 before, followed by either deactivation if the IN active sites or removal from the cloud chamber by settling ice crystals.

It was not possible to exactly determine the removal efficiency of ice crystals under the conditions of the experiments discussed here. At least a minor fraction of the ice particles formed during the expansion experiments with Sno$\max ^{\mathrm{TM}}$ were likely to evaporate in the chamber (see Fig. 6) and to release their ice nuclei to the chamber aerosol. Again, subsequent expansion with the remaining aerosol not listed in Table 2 didn't show any significant ice formation. Further experiments are needed to investigate and quantify a possible deactivation effect of IN active cells. We can conclude from experiments Bio02_06 to Bio02_10 that the ice nucleation activity of strains $P$. viridiflava FMu107 and $P$. syringae IceHv only occurs in a narrow temperature range around $-10^{\circ} \mathrm{C}$. Previous studies by Levin and Yankofsky (1983) and Ward and DeMott (1989) have also demonstrated that freezing induced by bacterial cells may occur only in narrow temperature ranges.

For the sample PS1, the fraction of IN active cells was also determined with the droplet freezing method as described in Sect. 3. The lower value of about $10^{-5}$ (the ratio between the number of IN active cells and the number of cells per $\mathrm{ml}$ in Table 1) compared to the AIDA could be due to the slightly warmer temperature. However, further droplet freezing and AIDA chamber experiments are needed for a better quantitative comparison of both methods. This is in particular important because previous laboratory experiments on the ice nucleation efficiency of bacterial cells have also indicated IN active fraction of the order of $10^{-5}$ (Yankofsky et al., 1981).

\section{Conclusions}

The ice nucleation efficiencies of five different $P$. $s y$ ringae, $P$. viridiflava and $E$. herbicola bacteria strains were 
investigated at simulated cloud conditions in the temperature range from -5.7 to $-15^{\circ} \mathrm{C}$. Within the detection limits of our experiments, no INA of the bacteria species was observed above $-7^{\circ} \mathrm{C}$. The results indicate that the bacteria investigated in the present study are mainly IN active in the temperature range between -7 and $-11^{\circ} \mathrm{C}$ with an IN active fraction of the order of $10^{-4}$. It should be investigated in appropriate cloud modelling studies if such low fractions of IN active bacterial cells could have an impact on cloud development and the initiation of precipitation through the ice phase. This of course also depends on the fraction of cloud droplets that contain bacterial cells and the actual properties of bacterial cell in clouds. Further studies are needed to measure the sources, distribution, and concentration of bacterial cells in the troposphere and to investigate the INA of cells extracted from cloud and rain water.

For the P. syringae strain 31R1, we measured an IN active fraction of $4 \times 10^{-4}$ at $-10^{\circ} \mathrm{C}$ in AIDA experiments, but only $4 \times 10^{-6}$ at $-9^{\circ} \mathrm{C}$ in freezing experiments with droplets deposited on a cooled aluminium foil. From the few droplet freezing experiments conducted during the present study we are not able to conclude if there is a systematic difference between AIDA results and the droplet freezing method according to Lindow (1982). This needs to be addressed in further experiments.

For Snomax ${ }^{\mathrm{TM}}$ cells an IN active fraction of about 0.2 was measured at temperatures around $-8^{\circ} \mathrm{C}$. A little ice activity was also observed around $-6^{\circ} \mathrm{C}$. The AIDA results are in reasonable agreement with Ward and DeMott (1989) who reported two distinct peaks of Snomax ${ }^{\mathrm{TM}}$ ice activity around -5 and $-8^{\circ} \mathrm{C}$. Some of the AIDA results indicate a possible deactivation of bacterial cells as active ice nuclei during the first ice activation event. Such a deactivation could have a remarkable impact on the role of IN active bacteria in cloud formation and should further be investigated.

Acknowledgements. The authors are appreciative to the AIDA operators and technicians for their skillful support during the Bio02 and Bio03 campaigns. We also acknowledge support from T. Schwartz for preparing the biological samples in the microbilogy lab of the Institute for Technical Chemistry of Forschungszentrum Karlsruhe, and from S. Wagner for assisting the programming and data analysis of the APicT-DLAS system. This work was funded within the Helmholtz Research Programme Atmosphere and Climate and contributes to the Helmholtz Virtual Institute on Aerosol-Cloud Interactions (VI-ACI).

Edited by: J. Kesselmeier

\section{References}

Amato, P., Parazols, M., Sancelme, M., Laj, P., Mailhot, G., and Delort, A. M.: Microorganisms isolated from the water phase of tropospheric clouds at the Puy de Dome: major groups and growth abilities at low temperatures, FEMS Microbiol. Ecol., 59, 242-254, 2007.
Bauer, H., Giebl, H., Hitzenberger, R., Kasper-Giebl, A., Reischl, G., Zibuschka, F., and Puxbaum, H.: Airborne bacteria as cloud condensation nuclei, J. Geophys. Res.-Atmos., 108, 4658, doi:10.1029/2003JD003545, 2003.

Benz, S., Megahed, K., Möhler, O., Saathoff, H., Wagner, R., and Schurath, U.: T-dependent rate measurements of homogeneous ice nucleation in cloud droplets using a large atmospheric simulation chamber, J. Photoch. Photobio. A, 176, 208-217, 2005.

Constantinidou, H. A., Hirano, S. S., Baker, L. S., and Upper, C. D.: Atmospheric Dispersal of Ice Nucleation-Active Bacteria - the Role of Rain, Phytopathology, 80, 934-937, 1990.

Ebert, V., Teichert, H., Giesemann, C., Saathoff, H., and Schurath, U.: Fiber-coupled in-situ laser absorption spectrometer for the selective detection of water vapour traces down to the ppb-level, Tech. Mess., 72, 23-30, 2005.

Franc, G. D. and DeMott, P. J.: Cloud activation characteristics of airborne Erwinia carotovora cells, J. Appl. Meteorol., 37, 12931300, 1998.

Jayaweera, K. and Flanagan, P.: Investigations on biogenic ice nuclei in the arctic atmosphere, Geophys. Res. Lett., 9, 94-97, 1982.

King, E. O., Ward, M. N., and Raney, D. T.: Two simple media for the demonstration of pyocyanin and fluorescein, J. Lab. Clin. Med., 44, 301-307, 1954.

Lee, R. E., Warren, G. J., and Gusta, L. V.: Biological Ice Nuclation and Its Applications, APS Press, The American Phytopathological Society, St. Paul, Minnesota, 1995.

Levin, Z. and Yankofsky, S. A.: Contact Versus Immersion Freezing of Freely Suspended Droplets by Bacterial Ice Nuclei, J. Appl. Meteorol., 22, 1964-1966, 1983.

Lindemann, J., Constantinidou, H. A., Barchet, W. R., and Upper, C. D.: Plants as a source of airborne bacteria, including ice nucleation active bacteria, Appl. Environ. Microb., 44, 1059-1063, 1982.

Lindow, S. E.: Population dynamics of epiphytic ice nucleation active bacteria on frost sensiteive plants and frost control by means of antagonistic bacteria, in: Plant Cold Hardiness and Freezing Stress, edited by: Sakai, A. and Li, P. H., vol. 2, Academic Press, New York, 1982.

Maki, L. R., Galyan, E. L., Chang-Chien, M. M., and Caldwell, D. R.: Ice nucleation induced by Pseudomonas syringae, Appl. Environ. Microb., 28, 456-459, 1974.

Mangold, A., Wagner, R., Saathoff, H., Schurath, U., Giesemann, C., Ebert, V., Kramer, M., and Möhler, O.: Experimental investigation of ice nucleation by different types of aerosols in the aerosol chamber AIDA: implications to microphysics of cirrus clouds, Meteorol. Z., 14, 485-497, 2005.

Möhler, O., Büttner, S., Linke, C., Schnaiter, M., Saathoff, H., Stetzer, O., Wagner, R., Krämer, M., Mangold, A., Ebert, V., and Schurath, U.: Effect of sulfuric acid coating on heterogeneous ice nucleation by soot aerosol particles, Journal of Geophysical Research-Atmospheres, 110, D11210, doi:10.1029/2004JD005169, 2005.

Möhler, O., Field, P. R., Connolly, P., Benz, S., Saathoff, H., Schnaiter, M., Wagner, R., Cotton, R., Krämer, M., Mangold, A., and Heymsfield, A. J.: Efficiency of the deposition mode ice nucleation on mineral dust particles, Atmos. Chem. Phys., 6, 3007-3021, 2006,

http://www.atmos-chem-phys.net/6/3007/2006/. 
Möhler, O., DeMott, P. J., Vali, G., and Levin, Z.: Microbiology and atmospheric processes: the role of biological particles in cloud physics, Biogeosciences, 4, 1059-1071, 2007, http://www.biogeosciences.net/4/1059/2007/.

Morris, C. E., Wen, A.-M., Xu, X.-H., and Di, Y.-B.: Ice nucleation active bacteria on Chinese cabbage in northern China : populations dynamics and characteristics and their possible role in storage decay, Phytopathology, 82, 739-746, 1992.

Morris, C. E., Georgakopoulos, D. G., and Sands, D. C.: Ice nucleation active bacteria and their potential role in precipitation, J. Phys. IV, 121, 87-103, 2004.

Morris, C. E., Sands, D. C., Vinatzer, B. A., Glaux, C., Guilbaud, C., Buffière, A., Yan, S., Dominguez, H., and Thompson, B. M.: The life history of the plant pathogen Pseudomonas syringae is linked to the water cycle, The ISME Journal, 2, 321-334, doi:10.1038/ismej.2007.113, 2008.

Sands, D. C., Langhans, V. E., Scharen, A. L., and Smet, G.: The association between bacteria and rain and possible resultant meteorological implications, Quarterly Journal of Hungarian Meteorological Service, 86, 148-152, 1982.
Vali, G., Christensen, M., Fresh, R. W., Galyan, L. R., Maki, L. R., and Schnell, R. C.: Biogenic Ice Nuclei. Part II: Bacterial Sources, J. Atmos. Sci., 33, 1565-1570, doi:10.1175/1520 0469(1976)033, 1976.

Wagner, R., Benz, S., Möhler, O., Saathoff, H., and Schurath, U.: Probing ice clouds by broadband mid-infrared extinction spectroscopy: case studies from ice nucleation experiments in the AIDA aerosol and cloud chamber, Atmos. Chem. Phys., 6, 47754800, 2006, http://www.atmos-chem-phys.net/6/4775/2006/.

Ward, P. J. and DeMott, P. J.: Preliminary experimental evaluation of Snomax, Pseudomonas syringae, as an artificial ice nucleus for wheather modification, Journal of Weather Modification, 21, 9-13, 1989.

Wood, S. E., Baker, M. B., and Swanson, B. D.: Instrument for studies of homogeneous and heterogeneous ice nucleation in freefalling supercooled water droplets, Rev. Sci. Instrum., 73, 39883996, 2002.

Yankofsky, S. A., Levin, Z., Bertold, T., and Sandlerman, N.: Some basic characteristics of bacterial freezing nuclei, J. Appl. Meteorol., 20, 1013-1019, 1981. 